(online) $=$ ISSN $2285-3642$

ISSN-L = $2285-3642$

Journal of Economic Development, Environment and People

Volume 8, Issue 3, 2019

URL: http://jedep.spiruharet.ro

e-mail: office jedep@spiruharet.ro

\title{
Giving a Chance to the Green Energy to Save our Planet Future
}

\author{
Layth Hazim Majit \\ ${ }^{1}$ The Bucharest University of Economic Studies (laithhazim02@gmail.com)
}

\begin{abstract}
The present paper focuses on analyzing the effects of using green energy on achieving sustainable development.

The competitive advantages and emphasized here and sustained to push finding farther ways to transform the world into a green planet as it was at its beginnings.

Under smart strategies implemented reasonably the green energy encourages smart investments and builds a better world for people and companies benefit.
\end{abstract}

Keywords: green energy, sustainable development, competitive advantages

JEL Codes: K30, K32, O11, O19, Q01

How to cite: MAJID, L. (2019). Giving a Chance to the Green Energy to Save our Planet Future. Journal of Economic Development, Environment and People, 8(3), 60-66. doi: http://dx.doi.org/10.26458/jedep.v8i3.636

\section{Introduction}

Welcome Achieving competitive advantages and long-term sustainable development are fundamental objectives of any establishment or country in the world. The green energy is the obvious engine for such an approach.

At present, most of the energies used in the world do belong to the traditional sources and scarcely allow the sustainable development. Therefore, new renewable energy sources must be identified and used to protect the environment, create new jobs and meet the growing demands and peoples' satisfaction for a better life.

Renewable sources, waste, wind, sun, salted water can change the effects against society, market and environment by using the green energy to achieving better advantages and sustaining the robust development. Countries like Germany or China can share their successful stories to improve the general experiences of other countries.

Green energy is the gateway to safety and the transit to protect the world from land and pollution threats caused by the use of harmful and non-renewable energies such as oil, coal and natural gas.

Green energy contributes to competitive advantages, sustainable development having a positive impact at macro, mezzo and micro levels, stimulating investment in the area, increasing health consumption and enhancing scientific research. 


\author{
(online) $=$ ISSN $2285-3642$ \\ ISSN-L = 2285 - 3642 \\ Journal of Economic Development, Environment and People \\ Volume 8, Issue 3, 2019 \\ URL: http://jedep.spiruharet.ro \\ e-mail: office jedep@spiruharet.ro
}

The results illustrate both potential social and societal impact highlighting the technical implications for design and operational systems development.

The research can contribute to better understanding the value of green energy in comparison with the harms the traditional ones can cause to people and society when their technical and societal efficiency are assessed.

\title{
2. Methodology
}

The study aims, in particular, to improve the knowledge on quantifying the measuring standards and calculate more precisely the effect of using green energy to gain competitive advantage; countries like Germany and China have overtaken the implementation of the green policies at high speed.

The identification of particular benefits of using green energy and monitoring impacts against the costs level of access those new sources requires special guidance to achieve the new goals in bringing to the light limits and obstacles to face in order to take advantage of a positive impact overall economy.

The scientific research relies on a deep socio-economic, financial and legal documentation linked to green energy and future investment projects.

The basic research method used takes care of the complex sensitivity and risk analysis for better solutions. Thus, starting from a variety of technologies, technology flows or special equipment it is explored the possibility to deploy them in certain locations across countries. The conclusion reached appears to serve as a foundation for any company to make decisions about adopting strategies for the competitive advantage of renewable energy sources.

Qualitative studies are used for the overall picture of renewable energy study; this becomes extremely important for modern society as fossil energy, still have followers (Lund \& Lund, 2008).

Due to the on-going climate change and the ever-increasing environmental pollution caused by different emissions, the energy conversion processes takes the place of fossil energies requiring the energy infrastructure reshape for the energy transition. This energy transition process takes place now at all three energy sectors (electricity, heat, mobility) holistically.

The transition to recoverable energy in any country needs combined efforts between different clusters of society to convince more categories to use renewable energy sources instead of conventional energy ones.

The use of renewable energies works to reduce the pressure on global fossil energy markets. To develop inter-connections between the process transformation and the availability of energy services, States make efforts to develop the exploitation of renewable resources and achieve energy security, environmental protection, etc. In this context, countries are interested in finding new ways and means to encourage the use of renewable energies.

A detailed analysis of how green energy generates fossil energy reduction underlies the new vision for the widespread use of renewable energy, not in conservative industries (the machinery industry, light industry, etc.) and in the industries of the future (IoT, Machine Learning, Artificial Intelligence), on the generation of batteries necessary for the use of certain components only from renewable energy or stored in various mobile devices. Also, green energy will become an infinite source of mobility of electronic devices due to its ability to regenerate endlessly (green energy sources are infinitely theories: sun, tide, wind etc.).

The statistics presented rely on data compiled in accordance with the accounting rules set out in Directive 2009/28 / EC on the promotion of the use of energy from renewable sources and calculated on the basis of 


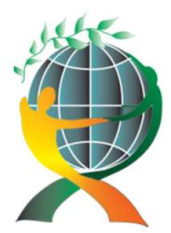

\author{
(online) $=$ ISSN $2285-3642$ \\ ISSN-L = $2285-3642$ \\ Journal of Economic Development, Environment and People \\ Volume 8, Issue 3, 2019
}

URL: http://jedep.spiruharet.ro

e-mail: office jedep@spiruharet.ro

the energy statistics provided for in Regulation 1099/2008 on energy statistics, most recently amended in November 2017 by Regulation no. 2017/2010.

The latest data available refers to the reference year 2016, for all EU Member States and the countries of the European Economic Area - Iceland and Norway but also Albania, Montenegro and the North Macedonia. In general, data looks complete, recent and reliably comparable between countries. Data was extracted from the internal production database (Eurostat).

The share of energy from renewable sources in gross final consumption of energy is identified as a key indicator for measuring progress on the basis of the Europe 2020 strategy for smart, sustainable and inclusive growth. This indicator can be considered as an estimate for the purpose of monitoring Directive 2009/28 / EC on the promotion of the use of energy from renewable sources - however, the statistical system in some countries for specific technologies in the energy sector from renewable sources is not yet fully developed to respond the requirements of this Directive; for example, ambient thermal energy for heat pumps is not reported by many countries.

All calculations take into account specific provisions of Directive 2009/28 / EC as a result of its amendment by Directive (EU) 2015/1513 of the European Parliament and of the Council of 9 September 2015 amending Directive 98/70 / EC on the quality of petrol and diesel fuels of diesel fuel and amending Directive $2009 / 28 / E C$ on the promotion of the use of energy from renewable sources. An important aspect to consider when interpreting data is the statistical review. It should be underlined that following the Renewable Energy Directive, states are monitoring more closely the flows of energy-based renewable energy products from their economies.

A particular situation is encountered in biomass consumption, as countries are launching more detailed surveys that allow them to obtain data on the final consumption of biomass energy. Several countries review their data accordingly, leading to an increase of their renewable energy share (Croatia, France, Lithuania and Hungary).

As defined in Directive 2009/28/EC on Renewable Energy, "gross final energy consumption" means energy products supplied for energy to industry, transport, household, services, including public services, agriculture, forestry and fisheries, electrical and thermal energy in the electricity and thermal energy sector, as well as the electricity and heat losses from distribution and transport. The energy available for final consumption is the total amount of energy resources available to consumers (private, commercial and industrial). This excludes the energy used in transformation processes (power plants, fuel refineries, highend furnaces) but includes the energy products that could be used for non-energy purposes (in chemical processes).

Energy production from non-renewable municipal waste was deducted from biomass's contribution to heating and electricity production. Consumption for pipeline transport was included in gross final consumption of energy, according to the sectorial classification of the Energy Statistics Regulation. In order to improve the accuracy and consistency of national statistics in calculating the share of energy from renewable sources, national calorific values were used, when available, to convert the quantities of all energy products into energy units instead of the default calorific values.

Recently, the Commission has drawn up definitive guidelines for accounting for energy from heat pumps. Some countries have not yet improved their national statistical system to take full account of all renewable energy sources. Despite the lack of a statistical methodology approved at the time of data collection and for reasons of completeness, the contribution of energy from renewable sources from heat pumps has been 


\author{
(online) $=$ ISSN $2285-3642$ \\ ISSN-L = $2285-3642$ \\ Journal of Economic Development, Environment and People \\ Volume 8, Issue 3, 2019 \\ URL: http://jedep.spiruharet.ro \\ e-mail: office jedep@spiruharet.ro
}

taken into account in cases where Member States have provided sufficient information. For these reasons, there are small differences between data used here and that published in the energy balance sheets.

The energy and energy balance statistics available from Eurostat do not distinguish between sustainable and non-sustainable renewable energy sources. This distinction is possible with the SHARE [Col, 2012] accounting tool developed by Eurostat, where reporting countries have to provide additional information in this respect. Therefore, unless otherwise explicitly provided, account must be taken of the fact that renewable energy sources include all renewable energy sources, both those meeting the sustainability criteria and those that do not meet such criteria.

\title{
3. Green Energy, Competitive Advantages and Sustainable Development
}

Countries enjoy sustainable growth reliable on green energy if it sustains and facilitate agriculture, health and education to develop. The lack of energy means lack of development, and this is proved by those 1.2 billion people without access to electricity (IRENA, 2019). That is why the European Union has made the fight against poverty as a central aspect of its development policy and has presented a program of over $600,000,000$ Euros for universal access to sustainable energy services and solutions renewable energy requiring governments to access renewable energy sources among the most demanding strategies.

The European Union's interest dates in the early 1990s when a policy to promote renewable energy production has been adopted to increase consumption and care for environment, society and people (Paavola, 2001). In 2000, the European Institutions reinforced the Green Energy Policy which was largely geared to the electricity sector, and the first EU Directive on Renewable Energy was issued in 2001, 2001/77CE.

Ambitious targets set for all EU countries emphasise the Union's gas consumption reduction by $20 \%$ and the integration of $20 \%$ of renewable energy into consumption, additionally, $10 \%$ of the total transport sector (Al-din, 2002). This directive imposed the EU members' full respect for their objectives. Member States drew up national plans explaining how they will achieve the desired objective (table 1).

Table 1. Share of renewable energies in gross final consumption of energy in\%

\begin{tabular}{|c|c|c|c|c|c|c|c|c|c|}
\hline Countries & 2011 & 2012 & 2013 & 2014 & 2015 & 2016 & 2017 & 2018 & 2020 \\
\hline BELGIUM & 6.3 & 7.2 & 7.5 & 8.0 & 7.9 & 8.6 & 9.1 & - & 13.0 \\
\hline HOLLAND & 4.5 & 4.7 & 4.7 & 5.5 & 5.7 & 5.9 & 6.6 & - & 14.0 \\
\hline FRANCE & 11.1 & 13.6 & 14.2 & 14.8 & 15.2 & 15.9 & 16.3 & - & 23.0 \\
\hline GERMANY & 12.5 & 13.6 & 13.8 & 14.4 & 14.9 & 14.9 & 15.5 & & 18.0 \\
\hline AUSTRIA & 30.1 & 31.0 & 32.0 & 33.2 & 32.8 & 33.0 & 32.6 & - & 34.0 \\
\hline U.K. & 4.2 & 4.2 & 5.3 & 6.5 & 8.4 & 9.2 & 10.2 & - & 15.0 \\
\hline UE28 & 13.4 & 14.7 & 15.4 & 16.2 & 16.7 & 17.0 & 17.5 & - & 20.0 \\
\hline
\end{tabular}

Source: Eurostat, Europe 2020.

This directive identified non-financial measures allowing operators to access and implement renewable energies, including strategic support for scientific research, development, innovation and other measures to 


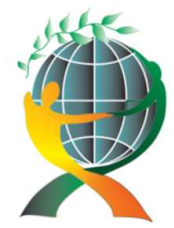

(online) $=$ ISSN $2285-3642$

ISSN-L = $2285-3642$

Journal of Economic Development, Environment and People

Volume 8, Issue 3, 2019

URL: http://jedep.spiruharet.ro

e-mail: office jedep@spiruharet.ro

facilitate renewable energy partnership to smooth the path of binding administrative rules and installation of infrastructures. The financial measures concern investment assistance, tax exemptions and the direct price support system. Giving the fact that renewable energy sources are permanently available, unsustainable and constantly renewable and clean, they do not lead to ecological contamination. Therefore, this energy consumption started to exceed in in non-OECD countries the OECD consumption (2007) projecting a growth of nearly two-thirds of the 739 quadrillion Btu global energy consumption by 2040 as seen in Fig.1.

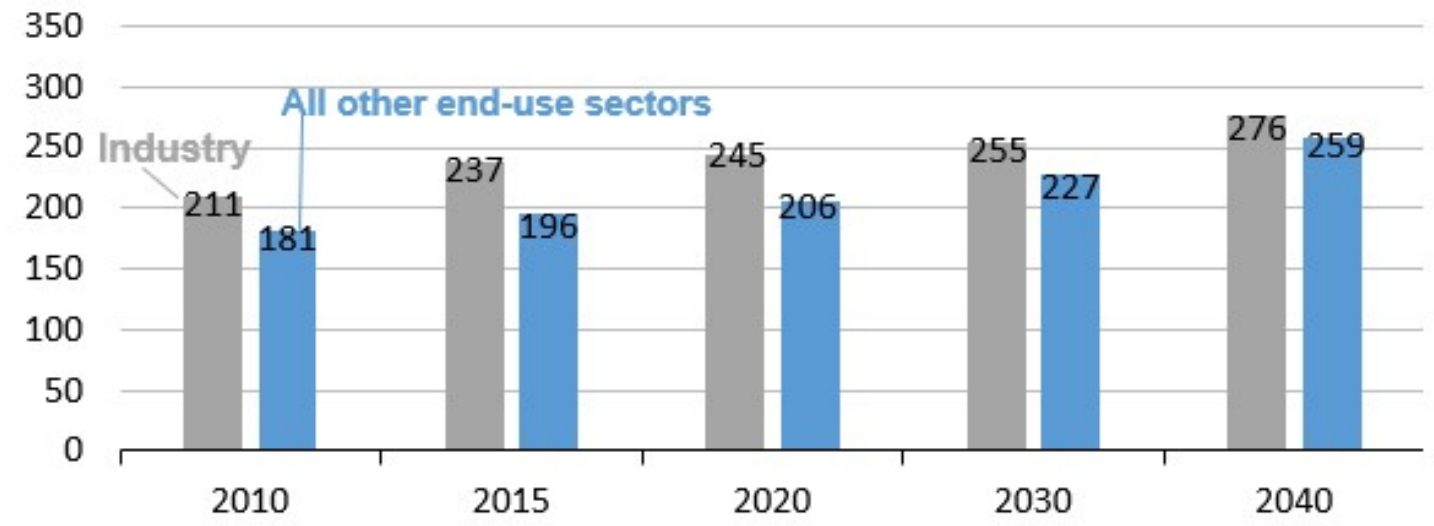

Fig 1: Competitive advantages and sustainable development

Source: EIA, International Energy Outlook 2018

With over half of the final gross final consumption of energy (53.9\%) of renewable energy, Sweden was by far the largest share in EU Member States in 2016, ahead of Finland (38.7\%), Latvia (37.2\%), Austria (33.5\%) and Denmark (32.2\%). At the opposite end, the lowest proportions of renewable energy sources were recorded in Luxembourg (5.4\%), Malta and the Netherlands (both 6.0\%), Belgium (8.7\%) and the UK and Cyprus (both 9.3\%). Compared to the most recent data available for 2016, the targets for France, the Netherlands and Ireland require each of these Member States to increase their share of renewable energy from final energy consumption by at least 6.0 percentage points (EIA, 2018).

11 of the Member States, including Croatia, Sweden and Estonia, have already exceeded their 2020 target. Data for Greece (2016) was estimated by Eurostat. By comparing the 2015-2016 average with the indicative trajectory set in the Renewable Energy Directive, it can be seen that France, Luxembourg, the Netherlands and the former Yugoslav Republic of Macedonia were below the values of the second indicative trajectory, while all the other countries were above them.

Today, the German economy enjoys its green miracle, emblazoned in the sun, wind and water, which generates fantastic financial profits and record export figures. The environment-based industry is also transformed into the 21st century. Germany is the world leader in this field. It is estimated that the green sector will reach 1 billion Euros in 2030. The world's largest production capacity for wind-powered units and the latest generation of power plants are world leaders in many high-efficiency devices.

It is not by chance that Germany pays special attention to engineering sciences, as well as renewable energy and environment. The medium-sized sector is growing in a large sector of the German economy and today is the main engine on the labour market. The proposed result of these efforts is green technology produced in Germany, which contributes to the creation of new jobs, in 2020 the number of workers in this 


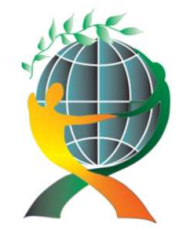

\author{
(online) $=$ ISSN $2285-3642$ \\ ISSN-L = $2285-3642$ \\ Journal of Economic Development, Environment and People \\ Volume 8, Issue 3, 2019
}

URL: http://jedep.spiruharet.ro

e-mail: office jedep@spiruharet.ro

sector will be higher than that of carmakers or car industry workers. Global, Germany is at the forefront. The German economy highlights the importance of renewable energy use and the expansion of energy consumption as well as the absorption speed and is in line with the economic aspect, which has a significant impact on the progress and development of competitive advantages and sustainable development.

The per capita energy consumption in India and Africa remains comparatively low despite high economic growth as shown in IEO2018 side cases while China started (2009) the implementation and construction of volumetric cell buildings for which the Government provides concessions for areas where projects are placed. China has become the world's largest producer of solar energy equipment between 2006 and 2011. Data confirm that Germany and China are among the top producers of green electricity and their growth rates are rising.

\title{
4. Contribution of Green Energy to Achieve Competitive Advantage Dimensions
}

The energy issue transcends the research framework and intersects the plan of general interest. Energy no longer affects our well-being and the way we handle it, but it takes a more comprehensive weight on the critical issues of societies. Renewable energies are one of the main sources of global energy beyond fossil energy that attracts international attention as a sustainable future alternative to fossil energy, which many countries, especially industrial ones, are looking to replace. During the recent years, there have been many discussions on the promotion of renewable energies as an effective mechanism to protect the environment and to enshrine the principle of sustainable development. Renewable energy resources will offer new prosperity opportunities to nations and economies without compromising capabilities.
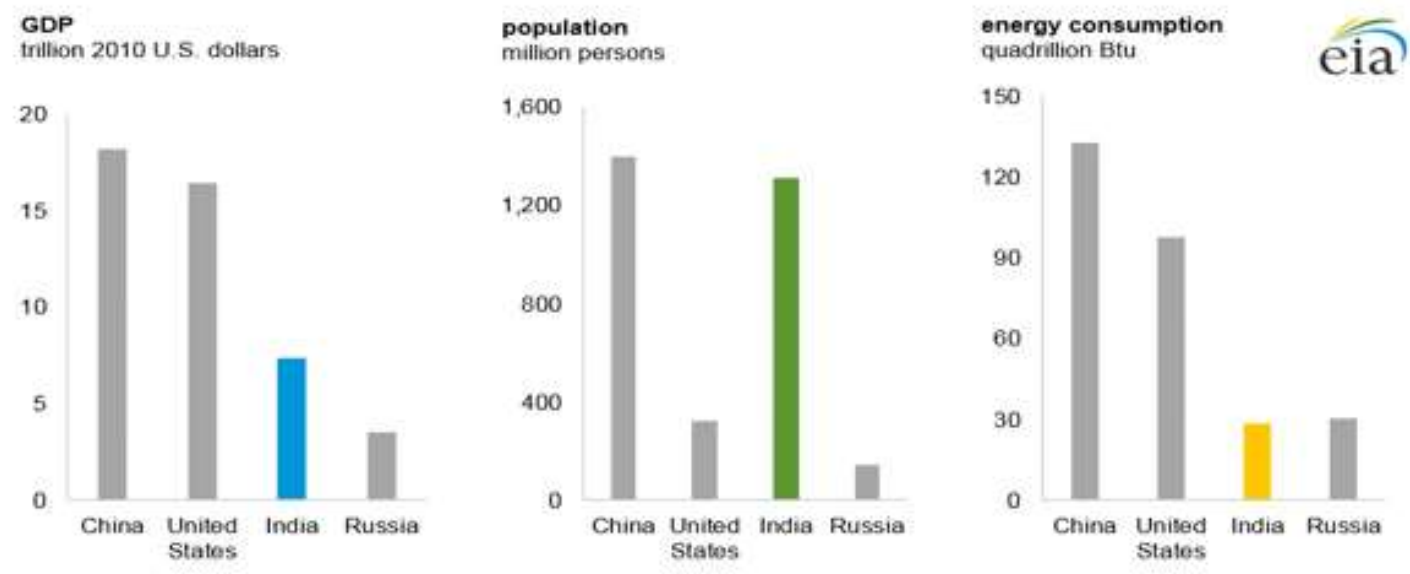

Fig 2: Tendencies in Renewable Energy 2018

Source: British Petroleum Statistical Review of World Energy,

Renewable energy remains an integral part of essential development to meet most of the human needs. It generates influence on the social, economic and environmental dimensions of sustainable development.

Sustainability builds on the link between development and how these renewable energies work is reflected in new objectives to remove the obstacles or braking factors of this new policy. 


\author{
(online) $=$ ISSN $2285-3642$ \\ ISSN-L = $2285-3642$ \\ Journal of Economic Development, Environment and People \\ Volume 8, Issue 3, 2019 \\ URL: http://jedep.spiruharet.ro \\ e-mail: office jedep@spiruharet.ro
}

It is expected that Asia will have the largest increase in energy consumption in non-OECD regions and many non-OECD projection shows that they will lead global economic growth.

Oil-producing countries, conservative consumers, international companies will be driven by the induced movements of the future to change their strategies and formulate new policies, to turn to supporting alternative energy sources as the main supporter of the health of the future society and the environment.

\title{
5. References
}

[1] BP, (2019), Statistical Review of World Energy, Eds.68., https://www.bp.com/content/dam/bp/businesssites/en/global/corporate/pdfs/energy-economics/statistical-review/bp-stats-review-2019-full-report.pdf

[2] Directive (EU) 2015/1513 of the European Parliament and of the Council of 9 September 2015 amending Directive 98/70/EC relating to the quality of petrol and diesel fuels and amending Directive 2009/28/EC on the promotion of the use of energy from renewable sources (Text with EEA relevance), http://data.europa.eu/eli/dir/2015/1513/oj.

[3] EIA, (2018), International Energy Outlook 2018, https://www.eia.gov/outlooks/ieo/

[4] Eurostat, Statistics explained, Europe 2020 headline indicators https://ec.europa.eu/eurostat/statisticsexplained/index.php/Europe_2020_headline_indicators

[5] International Renewable Energy Agency - IRENA, (2019), More People Have Access to Electricity, but World Is Falling Short of Sustainable Energy Goals, https://www.irena.org/newsroom/pressreleases/2019/May/More-PeopleHave-Access-to-Electricity-Than-Ever-Before

[6] Lund Henrik and Henrik Lund, (2009), The Choice and Modelling of 100\% Renewable Solutions, Renewable Energy Systems, 1st Edition, eBook ISBN: 9780080962993, Imprint: Academic Press, Elsevier

[7] Paavola, J., (2001), Towards Sustainable Consumption: Economics and Ethical Concerns for the Environment in Consumer Choices, Review of Social Economy, 59(2), pp: 227-248. http://www.jstor.org/stable/29770107

[8] Towler, Brian, (2014), The Future of Energy, eBook ISBN: 9780128010655 , Academic Press, Elsevier 